\title{
Bilim Ahlakı
}

\author{
Önder İLGİL̇ $\dot{a}^{a}$
}

\section{Albert Bayet, Bilim Ahlakı. 2. Basım, Yorum Yayınları, 1993.}

Albert Bayet'in orijinal adı "La Morale de la Science" olan eseri araştırma etiği, yayın etiği ve bilim etiği konularına olan ilgim nedeni ile dikkatimi çekmişti. Başlığı ile ilk anda bilimde etik açıdan olması gerekenlere değineceğini düşündüğüm eser, İkinci Dünya Savaşı’nda insanlığın düştüğü bunalımın da etkisi altında yapılmış temel sorgulamalar sunmakta. Eser, tekil olguları ayrıntılı olarak ele alan çalışmalara bir süre ara vermek isteyenleri, alanımıza zemin oluşturan değer dünyamızın temel düzlemlerinde kuşbakışı bir gezintiye çă̆ırıyor. Eser içerisinde iddia edilen fikirlere katılalım ya da katılmayalım, özgür düşüncenin ihmal edilebilecek derecede sakınımlarla ortaya konması ile imrendirici ve ilham verici. Eserin bu niteliğini, insanlığın savaşın dehşeti karşısında giriştiği ortak arayış ve kendisini felakete sürüklediğini düşündüğü eski anlayışları sorgulamasının yaratığı ortam ile açıklamak da olasıdır.

Pozitivist bir anlayışla temelde bilimin toplumsal ve bireysel ahlak konusunda belirleyici olması iddiasında olan Bayet işe bilim ve etik kesişiminde yer alan görüşlerin yetersizliğini göstererek başliyor. Bilimin ahlaka aykırı oluşu ve bilimin ahlak dışı olması savlarını reddediyor. Bilimin ahlaka aykırı olduğu görüşü ile hesaplaşırken alıntılarla önde gelen kişileri de tartışmaya katması okumayı daha da ilgi çekici kılıyor:

Einstein: "Bilim bugüne kadar köleler yaratmaktan başka bir işe yaramadı; savaş zamanında bizi zehirlemeye, paramparça etmeye yarıyor; barış zamanında da hayatımızı çekilmez, kararsız hale sokuyor. Bilimler, insanları kafa işlerine adayıp büyük ölçüde kölelikten kurtaracak yerde, onları makinanın kölesi yapmıştır. İşçilerin büyük bölüğü uzun ve sıkıcı günlerini tiksinti içinde geçirirler, ama bu bile, o zavallı ücretleri için titremekten alıkoyamıyor onları."

Bilime yönelik sonuçsalcı eleştirileri yine aynı biçimde Nazi Almanyası'nın mağlup edilmesi, makinelerin bazı yıpratıcı işleri devralması, artan ulaşım olanakları ve tıbbın kazanımları ile karşılıyor. Buna ek ve temel bir ayrım olarak, bilim ile teknik ve zanaatın farkını vurguluyor.

"Bilgin olarak, tek istediği bilgiye ulaşmaktı. İnsan olarak, onun da bir takım sevgileri, nefretleri, alışkanlıkları, önyargıları, çıkarları, tutkuları vardır. Elbet kendine özge bir ahlakı da vardır. Onun için bilgisini bu ahlakın buyruğuna verebilir."

Bayet ahlak olaylarının bilimi "ethiologie"nin diğer bilimler kadar pozitif biçimde ele alınabileceği iddiasındadır. Bunun birincil koşulu olarak ahlakın felsefe ile bağlarının kopartılması, apriori bir çalışma ile "ahlak dünyasının yasalarını" bulma çabasından uzaklaşılması, fizik dünya incelemelerindeki şaşmaz ve ölçülü bir yöntemin benimsemesi gerekliliğini öne sürmektedir. Bu düşünceler sşığında bilim, insan topluluklarının ahlaksal düşüncelerinin ne olduğunu, nasıl geliştiğini söyleyebilecek, ancak ne değerde olduklarını, ya da nasıl olmaları gerektiğini söyleyemeyecek konuma gelmektedir.

Bayet dinlerin ve felsefelerin yerine birey ve toplulukların değer dünyalarına yön vermek üzere bilimi önermektedir. Felsefe ile bağları kopartan bilim ahlakı, dinlerle arasında temel ayrılmayı dinde insanın doğruyu bulmuş ve bunun hazzı içerisinde iken, bilimde sürekli yeni doğrular aramak ve bu arayışın tadı çıkarmakta olması ile belirlemektedir. Dinlerin insanın üstünlüğünü bir takım değişmez doğruları

a Öğr. Gör., Ankara Üniversitesi Sağlık Bilimleri Enstitüsü, Tıp Tarihi ve Etik Doktora Programı, $\bowtie$ ilgili@medicine.ankara.edu.tr 
bilmenin kesinliğinde, biliminse gittikçe öğrenilecek daha çok şeyler bulunduğu inancının doğurduğu atılışlarda görmesini vurgulamakta, böylece bilim ahlakının ereksel yönünü de bir ölçüde su yüzüne çıkarmaktadır.

Eserde "aklın üstünlüğü” nün ardından bilim ahlakının ikinci ilkesi olan "birlik" ele alınmaktadır. En yüce ve tek gerçeği, bütün kafaların eninde sonunda karşılaşacağı gerçeği bulma iddiasında olan felsefede bu amaçla izlenecek yolların sayısız kollara ayrılmakta olduğu saptamasına yer verilmektedir. Bu durumun bireyleri kararsız, insanları ise daha da bölünmüş halde getirdiği dile getirilmektedir. Dinler düzleminde ise Voltaire'in "yaradancllık" 1 , Saint Simon'un "yeni Hristiyanlık"1 gibi birçok birlik arayışının sonuçsuz kaldığı ifade edilmektedir. Felsefe ve dinlerle hesaplaşmanın ardından Bayet, bilimin insanları birleştiren niteliğini vurgulanmaktadır.

Bilim ahlakının bir diğer ilkesi ise "özgürlük"tür. Düşüncenin mutlak bağımsızlığı araştırmanın ruhu olması itibarı ile vazgeçilmez yerini almaktadır.

Son olarak toplum bilimlerin ışı̆̆ında bir ilke olarak "hoşgörü" öne sürülmektedir. İnsan davranışlarının da yasalı olduğu, toplumsal gerekirciliğin kaçınılmaz olarak hoşgörüyü getireceği, bu bakış açısı ile insanların suçtan nefret edip, suçluya ise suçun asıl kurbanı diye acıyacağı öngörüsü paylaşılmaktadır. Esas amacı bireyden çok toplumu yükseltmek olarak ortaya koyan Bayet, bu sayede kişisel üstünlüğü sağlama çabasının yerine, herkesin yükselmesine karınca kaderince çalışmanın geçeceğini; kötülüğü kötülükle, nefreti nefretle ortadan kaldırma çabasının ortadan kaldıracağını savunmaktadır. Güncel adalet anlayışı ve ödül ceza dengesi gözeten dinler bu öngörülerle uyumsuzluk noktasında eleştirilmektedir.

Bilim ahlakında coşku ve duygusal doyum ispatlanmış gerçek aşkı, yeniyi bulan düşünce sevgisi ve kardeşlik duygusundan gelmektedir. Tanrısal varlıkların öngörülemez istekleri yerine, bilimsel olarak ortaya konacak tabiat yasalarının anlaşılır düzeninin yaşamda korkuyu ortadan kaldırmada daha etkin olacağı savunulmaktadır. Bayet'e göre insanı diğer varlıklar arasında özel kılan onun ispatlanmış gerçek alanını genişleterek işlerin en büyüğünü başarabilmesidir.

Kitapta yer yer diyalektikten ayrılarak duygusal ifadelerle fikirleri okuyucuya benimsetme çabası hissediliyor. Bunu yazarın savunduğu fikirlerle derinden özdeşleşmesine de yormak mümkün. Eserde pek çok kişiye, döneme ve anlayışa atıfta bulunulurken; hem etik üzerine temel bir akıl yürütme hem de okuma ve araştırmalar için ipuçları sunulmakta. Değerlendirmemi kitapta yer alan ilgi çekici alıntılardan birisini paylaşarak noktalamak istiyorum.

“... nihil a me humani alienum puto" (kendimden uzak tutmam insanca olanı)

Kestirmelerin olmadığını düşündüğüm ahlaki gelişim yolunda açık fikirle ilerleyen kişilerin okumaktan tat alacağı kanısındayım. 